\title{
A Safe Space for the Shah and His Women: The Practice of Quruq in the Safavid Period ${ }^{1}$
}

\begin{abstract}
This study traces the evolution of quruq - a Mongol term referring to something restricted, embargoed - from its original meaning as a royal burial or hunting ground off-limits to commoners, to what it came to signify in the (late) Safavid period - the embargoed, male-free and eunuch-controlled zone surrounding royal females during their appearance in the public arena. I show how the growing incidence of quruq in $17^{\text {th }}$-century Iran reflects the transition of the Safavid polity from a steppe dispensation to a sedentary order, turning what used to be the freerange mobility of an ambulant court into controlled mobility fit for urban royal living. The final part of the study documents how quruq persisted long beyond the safavids, only to fade in the late $19^{\text {th }}$ century.
\end{abstract}

Keywords: Safavid Iran, female seclusion, quruq

\section{Introduction}

The Mongol term qurq or quruq, قرق, also sp. qūruq, قورق, or qurūq, قروق, refers to that which is restricted, ritually forbidden, taboo. ${ }^{2}$ Its origins appear to lie in Inner Asia. According to Doerfer, in pre-Mongol sources the word only occurs once, namely in Narshakhi's account of Shams al-Mulk Nasir Khan, who ruled at Bukhara from 1068 to $1080 .^{3}$ The earliest proper documentation of the term

${ }^{1}$ Most of the research and writing of this article took place during my time as the Agnes Gund and Daniel Shapiro member at the Institute for Advanced Study in Princeton in 2017. I thank Kamran Arjomand, George Bournoutian, Emine Fetvac1, Charles Melville, John Woods, as well as the audience at the ASPS conference in Tbilisi, Georgia, March $18^{\text {th }} 2018$, where I presented a version of this paper, for their comments and suggestions.

${ }^{2}$ G. Doerfer, Türkische und mongolische Elemente im Neupersischen. Unter besonderer Berücksichtigung älterer neupersischen Geschichtsquellen vor allem der Mongolen- und Timuridenzeit, vol. 3, Wiesbaden 1967, p. 444.

${ }^{3}$ See Abu Bakr Muhammad b. Ja far al-Narshakhi, Tarikh-i Bukhara, trans. Abu Nasr Ahmad Muhammad b. Nasr al-Qubadi, Tehran 1351/1972, p. 41, where the term occurs as ghüruq. 
comes to us from the Mongol era. In Mongol society quruq, which also occurs as $q \bar{u} f i q$ and ghüruq, referred specifically to a royal burial site, which was forbidden ground, off-limits to outsiders, and guarded by detachments of soldiers. Since the actual site of the grave was not indicated in any way, even members of the guard were ignorant of where the actual burial site was located. The ones who stood guard in front of cemeteries or the palace were called quruqchis, mounted guardsmen. ${ }^{4}$ The term quruq was also reserved for other royal preserves, such as parks, enclosed meadows where only royal horses were allowed to graze, or royal hunting grounds. ${ }^{5}$ It shares this meaning with the original concept of the forest, which probably comes from late Latin, forestem silvam, the outside woods, and in the Middle Ages came to mean an "extensive tree-covered district, set aside for royal hunting and under the protection of the king". ${ }^{6}$ The capaciousness of the term and the contradictory elements it contained are neatly captured in Thomas Allsen's reference to quruq in the premodern Inner Asian world as a "term that could designate the territory around a monastery in which hunting was prohibited or designate a park and preserve where elites killed animals in large numbers".

It remains unclear how the meaning of the term and the practice evolved in the subsequent period, connecting the Mongols to the Safavids via the Timurids. In the Timurid sources, the term quruq occurs infrequently, mostly, as it had done in earlier times, to denote geographical spaces. Nizam al-Din Shami's Zafarnama has only one reference to quruq. ${ }^{8}$ In Hafiz Abru's Zubdat al-tavarikh, the term occurs eighteen times, in each case referring to a burial site. ${ }^{9}$ The Matla 'al-Sa 'dayn contains fourteen references to quruq. ${ }^{10}$ Sharaf al-Din 'Ali Yazdi, Zafar-nama has three references to quruq. ${ }^{11}$ And Khvandamir's early $16^{\text {th }}$-century Habib al-siyar

\footnotetext{
${ }^{4}$ V.V. Barthold, J.M. Rogers, The Burial Rites of the Turks and the Mongols, "Central Asiatic Journal" 1970 , no. 14 , pp. 204-205.

${ }^{5}$ G. Doerfer, op. cit., vol. 3, p. 445.

${ }^{6}$ Online Etymology Dictionary: http://www.etymonline.com/index.php?term=forest (access: 2.05.2019).

7 T.T. Allsen, The Royal Hunt in Eurasian History, Philadelphia 2006, pp. 116-117.

${ }^{8}$ Nizam al-Din Shami, Zafarnama, Histoire des conquêtes de Tamerlan, ed. F. Tauer, Prague 1937, p. 114, referring to Tubalik Quruq.

${ }^{9}$ Hafiz-i Abru, Zubdat al-tavarikh vol. 1(1-2), ed. Hajj Sayyid Javadi, Tehran 1380/2001, p. 217, quruq-i Ujan; p. 293, quruq-e Ujan; p. 537, quruq-i Sultaniya; p. 583, quruq-i Sultaniya; p. 600, quruq-i Sultaniya; p. 628, quruq-i Ujan; p. 630, quruq; p. 630, quruq-i Sultaniya; p. 640, quruq-i Fars; p. 651, quruq-i Ujan; p. 664, quruq-i Arghun; p. 717, quruq-i Hamadan; p. 721, quruq; p. 764, Alma quruq; vol. 2(3-4), p. 41, quruq-i Sultaniya; p. 74, quruq-i Arghun; p. 355, quruq-i Sultaniya; p. 705, quruq-i Urdubash.

${ }^{10}$ Kamal al-Din 'Abd al-Razzaq Samarqandi, Matla'-i sa'dayn va majma' al-Bahrayn, vol. 1, ed. 'Abd al-Husayn Nava'I, Tehran 1383/2004, p. 60, quruq-i Sultaniya; p. 313, quruq-i Ujan; vol. 2, p. 506, quruq-i Sultaniya; p. 532, quruq-i Sultaniya; p. 585, quruq-i Ujan; p. 593, quruq-i Arghun; p. 609, quruq-i Hashtrud; p. 638, quruq-i Guk; p. 639, quruq-i Gul; vol. 3, p. 22, quruq-i Sultaniya; p. 82, quruq-i Arghun; p. 122, quruq-i Sultaniya; p. 310, quruq-i Qurqan; vol. 4, p. 942, quruq-i Hazarjarib.

${ }^{11}$ Sharaf al-Din 'Ali Yazdi, Zafar-nama, vol. 1-2 paginated as one, ed. 'Abd al-Husayn Nava'i, Muhammad Sadiq, Tehran 1387/2008, p. 171, about the burial of Chingis Khan; p. 187, about the burial of Arghun; and p. 618, Tubalik Quruq.
} 
only mentions the term twice. ${ }^{12}$ The term also occurs in the Babur-nama, where it refers to a princely (hunting) reserve. ${ }^{13}$

In later times, quruq seems to have lost its direct connection to royal burial sites. Yet it retained its original meaning of something that is taboo, embargoed, declared off-limits to anyone but the ruler - and thus closely resembles the meaning of the Arabic-Islamic term haram. The French traveler Jean de Thévenot, describing mid-1 $17^{\text {th }}$-century Iran, offers a good example of this. According to him, if the shah had his eye on a particular food item, anything he took a fancy to, he would declare it quruq, which meant that no one would dare sell it to anyone but the monarch. As a result, the item in question would be unavailable at any price. Fish and fowl thus had been unavailable for weeks on end during Thévenot's stay in Isfahan. ${ }^{14}$

Two late Safavid chronicles offer good examples of quruq as a banned or restricted practice. Muhammad Ibrahim b. Zayn al- 'Abidin Nasiri and Sayyid Abu Talib Musavi Findiriski both employ the term to denote various activities that Shah Sultan Husayn proscribed for being contrary to the shari 'a upon acceding to the throne in August 1694. These included the consumption of alcoholic beverages and frivolous pastimes such as visiting coffeehouses, flying kites, and playing cards. The ultimate target of these restrictions were women, for the royal decree forbade them to go out unaccompanied by male relatives and to show their faces to anyone but their husbands. ${ }^{15}$

\section{The Meaning of Quruq in Safavid Iran}

The available sources suggest that between the early $16^{\text {th }}$ and the early $17^{\text {th }}$ century the term quruq evolved from denoting a sacred, secluded space to a specific sacred and secluded space involving the ruler's inner court, otherwise known as the harem, in motion. It is difficult to say with any precision how and at what time this transition occurred. As late as the Timurid period, the women of the court, in keeping with the Turkic customs of the steppes, were not secluded and played a prominent role in public affairs. Royal women attended the assemblies, quriltays, of Temür (Timur Lang, r. 1370-1405) unveiled, and court females were allowed to organize their own parties. As they had done under the Mongols, women in the Timurid period played a visible role in public life, and even under Temür's $15^{\text {th }}$ -century descendants they did not lose that freedom. Caterino Zeno, the Venetian

${ }^{12} \mathrm{Kh}^{\mathrm{v}}$ andamir, Tarikh-i habib al-siyar, vol. 4, ed. Jalal al-Din Huma'I, Muhammad Dabir-Siyaqi, Tehran 1362/1983, p. 231, quruq-i ziba, and p. 283, quruq-i Budina. I thank John Woods for kindly providing me with the references in footnotes 7-11.

${ }^{13}$ Zahiru' d-dīn Muhammad Babur Pādshāh Ghāzī, The Bābur-nāma in English, trans. A.S. Beveridge, London 1921, p. 80.

${ }_{14}$ J. de Thévenot, Les voyages de Mr. De Thévenot. Suite de voyage au Levant, vol. 3, Paris 1727, pp. 337-338.

${ }^{15}$ Muhammad Ibrahim b. Zayn al-'Abidin Nasiri, Dastur-i shahriyaran, ed. Muhammad Nadir Nasiri Muqaddam, Tehran 1373/1994, pp. 30-33; and Sayyid Abu Talib Musavi Findiriski, Tuhfat al'alam (dar awsaf va akhbar-i Shah Sultan Husayn Safavi), ed. Rasul Ja fariyan, Tehran 1388/2009, p. 82. 
envoy who visited the court of the Aq-Quyunlu ruler Uzun Hasan in the 1470s, suggests a similarly visible role for elite women with his claim that the royal women "walk about the cities and the fortresses, or ride with their husbands to the war", adding that, "in the following of the king they cover their faces with nets of horsehair, so thick that they can easily see others, but cannot be seen by them". ${ }^{16}$

Some of this visibility is still apparent in the early Safavid period, most famously in the observation that the women of Shah Isma il (r. 1501-1524) rode horses and participated in battles. ${ }^{17}$ The Portuguese ambassador Fernão Gomes de Lemos, describing the army camp of Isma il in 1515, speaks of women who were not shy to show themselves in public. ${ }^{18}$ Antonio Tenreiro, who visited Iran in 1523-1524, accompanying the Portuguese ambassador Balthasar Pessoa, observed how the women in Shah Isma'il's entourage had their faces veiled but rode like the men. ${ }^{19}$ There is also the well-known claim of Michele Membré, the Venetian envoy who visited Shah Tahmasb's court in 1539, that the "ladies ride through town like men and go with maids instead of grooms; and they go with the face covered with a white kerchief, so only the eyes are seen". ${ }^{20}$ And finally we have Vincentio d'Alessandri, another Venetian ambassador who, visiting the court of Shah Tahmasb in 1572, noted that the royal women "at times have permission from the king to come out of the palace". He himself claimed to have seen the mother of Sultan Mustafa Mirza, one of Shah Tahmasb's sons, "come out with her face covered with a black veil, accompanied by four slaves and six men on foot". ${ }^{21}$

Under the Safavids one sees a retreat of women from public life, as reflected in the emergence of the harem as a separate building. ${ }^{22}$ Persian-language sources are sparing in their references to the most conspicuous manifestation of quruq in the $17^{\text {th }}$ century. Indeed, until the reign of Shah 'Abbas I (1587-1629), the term denoting a secluded female space does not appear in any of the Safavid chronicles. Narrating the year 1001/1592-1593, chronicler Khuzani Isfahani uses quruq, spelled qūrugh, in the traditional meaning of a restricted hunting ground (in Gilan). ${ }^{23}$ Another chronicler, Muhammad Ma'sum b. Khajigi Isfahani, writing

16 C. Zeno, Travels in Persia, [in:] A Narrative of Italian Travels in Persia in the Fifteenth and Sixteenth Centuries, ed. Ch. Grey, London 1873, p. 13. For more examples, see M. Szuppe, Status, Knowledge and Politics: Women in sixteenth-Century Safavid Iran, [in:] Women in Iran from the Rise of Islam to 1800, ed. G. Nashat, L. Beck, Urbana-Chicago 2003, pp. 142-144.

17 According the German clergyman-Orientalist Salomon Schweigger, many women had been found among the casualties after the battle the Safavids fought and lost against the Ottomans at Chaldiran in 1514. See S. Schweigger, Ein newe Reyssbeschreibung auss Teutschland nach Constantinopel und Jerusalem, ed. R. Neck, Graz 1964, p. 81.

18 In R.B. Smith (ed.), The First Age of the Portuguese Embassies, Navigations and Peregrinations in Persia (1507-1524), Bethesda, MD 1970, p. 49.

19 Ibidem, pp. 75, 85-86.

20 M. Membré, Mission to the Lord Sophy of Persia (1539-1542), trans. and ed. A.H. Morton, London 1993, p. 31.

21 Vi d'Alessandri, Narrative of the Most Noble Vincentio d'Alessandri, [in:] A Narrative of Italian Travels in Persia..., op. cit., p. 217.

22 B. O'Kane, From Tents to Pavilions: Royal Mobility and Persian Palace Design, "Ars Orientalis" 1993, no. 23, p. 256.

${ }^{23}$ Fazli Beg Khuzani Isfahan, A Chronicle of the Reign of Shah 'Abbas, ed. K. Ghereghlou, 2 vols paginated as one, Exeter 2015, vol. 1, p. 125. 
half a century later, employs the term, qüruq, in the way Jean de Thévenot did, as commodity embargoed by the monarch or the court, referring to the royal silk export monopoly that Shah 'Abbas had declared in 1619 and that was abolished when Shah Safi came to power in $1629 .{ }^{24}$ Although the trajectory of this process thus remains unclear, it is likely to have followed the growing sedentarization of the court, culminating in Shah 'Abbas I's choice of Isfahan as his capital - arguably Iran's first "real" capital - in the late 1590s. With the court's diminishing mobility came a great increase in the size and complexity of the royal court, and this entailed the growth of the number of women attached to the royal harem as well as the of the eunuchs tasked to supervise and protect them. ${ }^{25}$ The radical and seemingly abrupt change in the meaning of the term quruq as a "safe space" for royal women reflects this development. The Persian-language sources, deeming the topic inappropriate, are reticent about the process. Documentation about this type of quruq of needs comes mostly from foreign observers. Yet the first clear reference to the evolving practice of quruq, albeit without the employment of the term, occurs in a popular history of Shah 'Abbas whose author, Mullah Jalal al-Din Munajjim, may have found himself less bound by such strictures than the more formal chroniclers of the age. ${ }^{26}$ The Roman nobleman-traveler Pietro Della Valle, who lived in Isfahan in 1618-1619, next unambiguously refers to Shah 'Abbas I's habit of forcing all males from any area he planned to visit with his females consorts, and calls the custom "natural", since in Iran "no man was allowed to see the women of the king". ${ }^{27}$ Another clear reference to Shah 'Abbas's quruq is found in the words of the agents of the English East India Company who in 1625 wrote about 'Abbas to the effect that, "till their arrival at Spahan, he going before with his women, and no man being suffered but eunuchs to come within a league of him". ${ }^{28}$

Quruq involving royal women from this time onward came in different versions, ranging from the relatively quiet and unobtrusive to the noisy and spectacular. In its simplest manifestation, quruq was invoked when a woman of rank decided to go to town, which, according to the French merchant-traveler Jean Chardin, occurred almost invariably late at night. Whenever this happened, her guardians, the quruqchis, would ride ahead of the female suite at a distance of 100 paces, followed by a posse shouting quruq, quruq, at which signal everyone would scurry away, struck with fear, "as if fleeing from an unchained lion", as Chardin put it. ${ }^{29}$

${ }^{24}$ Muhammad Ma'sum b. Khajigi Isfahani, Khulasat al-siyar. Tarikh-i ruzgar-i Shah Safi Safavi, ed. I. Afshar, Tehran 1368/1989, p. 39.

${ }^{25}$ M. Brosset (ed.), Collection d'historiens arméniens, 2 vols., St. Petersburg 1874, vol. 2, p. 484.

${ }^{26}$ Mulla Jalal al-Din Munajjim, Tarikh-i 'Abbasi ya ruznama-yi Mulla Jalal, ed. Sayf Allah Vahid Niya, Tehran 1366/1987, p. 331.

27 P. Della Valle, Delle conditioni di Abbàs Rè di Persia, Venice 1628; repr. Tehran 1976, p. 105.

${ }^{28}$ W. Bell et al., Oct. 15 1624, and 9 Jan. 1625, Ispahan, [in:] Calendar of State Papers Colonial, East Indies, China and Japan, Volume 4, 1622-1624, ed. W.N. Sainsbury, London 1878, p. 163.

29 J. Chardin, Les voyages du Chevalier Chardin, en Perse et aux Indes et autres lieux de l'Orient, 10 vols and atlas, ed. L. Langlès, Paris 1810-1811, vol. 6, pp. 32-34. The quruqchis were under the control of the tufangchi-aqasi, or the commander of the musketeers. 
A more elaborate and logistically complex form of quruq was the embargo that was declared whenever the shah went out riding with all or part of his female train. Quruq in those circumstances entailed a ban for all males above the age of six to be in the vicinity of the route taken by the royal suite. This was particularly onerous whenever the quruq was held within the urban area of Isfahan, for it meant not just that the streets within one mile of the route had to be cleared but that all men had to leave their houses and move to a different part of town; if they could not find lodging with relatives or friends, they had to go to the countryside for the duration of the shah's outing. The day prior to this event, several quruqchis would ride through the streets announcing the outing with trumpets and kettle drums. Following this proclamation, the prospective route was closed off with a fence covered with the same cotton cloth from which tents were made. Attached to pickets, the cloth formed an enclosure that prevented people from laying eyes on the royal suite. On the day itself, about two hours before the event, the $q u$ ruqchis would reappear and clear the streets. By this time only women, girls and eunuch slaves were supposed to be in the homes within the target zone. Any male person caught during their second visit would risk being executed on the spot. Total silence would next descend on the embargoed area. The shah then appeared, riding at the head of the royal suite. His women followed, on horses or mules, veiled, the bridle of each horse held by a black eunuch. Surrounding the troupe rode mounted white eunuchs armed with long batons. The rear of the suite was composed of mounted guards, yasaqchis. If the royal women traveled without the shah accompanying them, they would be carried in litters, so-called kajava, hanging on the side of camels. The walls of the houses which the cavalcade passed would be hung with precious red carpets. The embargo would last until the end of the evening, "when the king return[ed] with his suite, illuminated by torches and very many lights which the eunuchs are accustomed to hold ready". ${ }^{30}$

Quruq also applied when the shah visited the countryside with his womenfolk to engage in sightseeing or hunting. A half hour before the royal suite went out riding in the environs of Isfahan, the quruqchis would chase all the men out of the villages on its path. ${ }^{31}$ The German secretary of the Holstein embassy to the court of Shah Safi I (r. 1629-1942), Adam Olearius, reports how in 1637 the shah set

30 P. Della Valle, Viaggi di Pietro della Valle il pellegrino 2 vols, ed. G. Gancia, Brighton 1843, vol. 1, pp. 694-695; R. du Mans, Estat de 1660, and Estat de 1684, [in:] Raphaël du Mans missionnaire en Perse au XVIIe siècle 2 vols., ed. F. Richard, Paris 1995, vol. 2, pp. 71-72 and pp. 349-350; J.-B. Tavernier, Les six voyages de Jean Bapt. Tavernier ... en Turquie, en Perse, et aux Indes, 2 vols., Paris 1686, vol. 1, pp. 615, 636; J. Chardin, op. cit., vol. 6, pp. 33-40; vol. 9, pp. 552-553; E. Kaempfer, Exotic Attractions in Persia, 1684-1688. Travels and Observations, trans. and annotated W. Floor, C. Ouahes, Washington 2018, p. 167; B. Carré, Le Courier du Roi en Orient. Relations de deux voyages en Perse et en Inde 1668-1674, Paris 2005, p. 264; N. Sanson, Estat présent du royaume de Perse, Paris 1694, pp. 83-84; G. Gemelli-Careri, Giro del mondo 6 vols., Naples 1699, vol. 2, p. 172; F.C. Schillinger, Persianische und Ost-Indianische Reis: Welche Frantz Caspar Schillinger von Ettlingen der Marggrafschafft Baaden... durch das Türckische Gebiet im Jahr 1699 angefangen und 1702 vollendet, Darbey ein warhaffter Bericht etlicher Begebenheiten die sich Zeit solcher vierjährigen Reise ... zugetragen, Nuremberg 1701, p. 220. The quote is from P. Bedik, A Man of Two Worlds. Pedros Bedik in Iran 1670-1675, trans. and annotated C. Ouahes, W. Floor, Washington 2014, p. 248.

31 J. Chardin, op. cit., vol. 6, p. 34. 
out on a hunt with his female entourage. A few hours before they left, the quruqchis, or tzarzi, jarchiyan, as Olearius calls them, went around those alleyways and streets of Isfahan through which the cavalcade was to travel, to proclaim quruq. Olearius also relates how the women who had been carried in litters on camelback during the trip mounted horses the moment they arrived at the hunting ground. Carrying bows and arrows and falcons, like the men, they went on a separate female hunt, with men forced to keep at least a distance of a quarter of a (German) mile, or more than 2,000 meters. $^{32}$

Quruq was also observed in the army camp, whenever high-ranking officers brought their harems with them, as they did at times. The French missionary Poullet described how, here too, eunuchs made sure that no one would set eyes on the women, whose camp was at some remove from the regular army camp. ${ }^{33}$

The most elaborate and spectacular form of quruq, finally, is also the first one to be mentioned and described in some detail in the Tarikh-i 'Abbasi. Jalal al-Din Munajjim records how at one point in 1016/1607 Shah 'Abbas I made the bazaar as well as the royal square of Isfahan exclusively available to females for a few nights. Eunuchs put in charge of the organization made sure that only women could enter the area. Since all vendors had to be female as well, shop owners had female relatives staff their shops. Handsome eunuchs in elegant dress took care of the shops of owners without female relatives. A year later the shah institutionalized this ladies-only policy. He issued an ordinance that allowed women to go out and entertain themselves once a week by making the famous Chahar Bagh Avenue and its extension, the bridge of the thirty-three arches over the Zayanda Rud, available only to female visitors each Wednesday. ${ }^{34}$

Jalal al-Din Munajjim's story is confirmed both by Pietro Della Valle and the Spanish ambassador Don García de Silva y Figueroa, who twelve years later provide details about a similar approach to the festivities surrounding the shah's return from his winter residence in Mazandaran. On Monday 17 June 1619, just a day after he had entered the city - having tarried for days in the vicinity waiting for the propitious moment of entry recommended to him by his astrologer (Mullah Jalal) - Shah 'Abbas announced a party celebrating his return to the capital. The announcement came with an edict commanding all the beautiful women of Isfahan, Muslim and non-Muslim, to present themselves at the entrances to the bazaar on the day of the celebration. In the morning of the day in question, the shops were covered with multi-colored silk canopies, food and sweets and beverages were laid out, and the bazaar and the royal square adjacent to it were decorated with thousands of lanterns and candles. ${ }^{35}$ The preparations finished, all the male shop owners and attendants were summoned to leave and the area became a no-go zone for males. Guards armed with sticks made sure that no men of any age would

32 A. Olearius, Vermehrte newe Beschreibung der muscowitischen und persischen Reyse, Schleswig 1656 , repr. Tübingen 1971 , p. 529.

33 Sr. Poullet, Nouvelles relations du Levant, 2 vols., Paris 1668, vol. 2, p. 148.

34 Jalal al-Din Munajjim, op. cit., pp. 331, 361.

35 For this type of illumination, chiraghani, see M. Omidsalar, Čerāḡān̄̄, [in:] Encyclopaedia Iranica, vol. 5, London 1991, pp. 264-265. 
approach the area. Beginning at about noon, a great throng of women accompanied by female relatives, mothers and sisters, began to arrive at the entrances to the bazaar, where eunuchs draped in brocade finery, sporting precious turbans and carrying gold-trimmed canes inspected them by lifting their veils, allowing the pretty ones in and dismissing the ungainly ones. Don García, whose servants were allowed to watch the entrances from a distance, claims that more than 3,000 women were vshered in. Della Valle, who based his story on information provided by his Armenian-Iranian wife, who herself took part in the festivities, says that, upon entering the free zone, women took off their veils and started enjoying themselves with music and dance, the scene illuminated by the light of the lanterns and candles refracted in a sea of glittering mirror fragments set into the walls and porticoes of the buildings surrounding the square. ${ }^{36}$ On the first night of the festival the shah himself had briefly visited the area with his female retinue. In the morning the women were released, with the exception of some Armenian ones who had been chosen for the shah's harem. ${ }^{37}$

Della Valle corroborates Jalal al-Din Munajjim's statement that such controlled freedom was or became a regular occurrence in Isfahan, and that the shah often attended with his own women, mixing freely with the crowd. He also notes that almost all the cities of Iran were the scene of similar events. ${ }^{38}$ Unfortunately, we only have information about Shiraz. In that city in the same period, women were allowed to go out freely for fourteen days around the time of the Persian New Year, Nowruz. ${ }^{39}$

Over time, judging by the absence of references in the later sources, the custom of granting women their own temporary public sphere in such an organized fashion fell into abeyance. After the reign of Shah 'Abbas I, quruq more and more came to stand for the protected excursions of the shah and his female retinue. Yet the very fact that royal women still went out can be construed as relative freedom, at least compared to the restrictions imposed on the women of the Ottoman sultan, who seem to have been more sequestered than their Safavid counterparts. ${ }^{40}$

36 The reference to glittering mirror fragments is to so-called a 'ina-kari, broken-mirror decoration.

37 P. Della Valle, Viaggi..., vol. 2, pp. 7-10; and Don García de Silva y Figueroa, Comentarios de la Embaxada al Rey Xa Abbas de Persia (1614-1624), ed. R.M. Loureiro, A.C. Costa Gomes, V. Resende, 2 vols paginated as one, Lisbon 2011, vol. 2, pp. 526-527. I have followed Della Valle's chronology and dating here, which is more precise than those of the Spanish envoy. Iskandar Bayg Turkaman (Munshi), Shah 'Abbas's official historiographer, summarily records the shah's arrival in the capital in 1028/1619, three months after Nowruz, i.e. in June, but ignores the women-only festival. See his Tarikh-i 'Alam-ara-yi 'Abbasi, 2 vols. paginated as one, ed. I. Afshar, $2^{\text {nd }}$ ed., Tehran 1350/1971, vol. 2, p. 945. The Russian envoy, Ivan Ivanovich Chicherin, does not refer to the event because he had no yet arrived in Isfahan on June $17^{\text {th }}$ (June $7^{\text {th }}$ according to the Julian calendar). He would make his entry into the capital the following day. See P.P. Bushev, Istoriia posols stv $i$ diplomaticheskikh otnoshenii russkogo i iranskogo gosudarstv v 1613-1621 gg., Moscow 1987, pp. 212-213.

38 P. Della Valle, Delle conditioni..., pp. 49, 107-108.

39 See T. Herbert, Travels in Persia, 1627-1629, London 1928, p. 74.

40 During the 1582 circumcision ceremony of Sultan Murad III's son, a viewing pavilion was set up for the women of the harem, who were able to watch the ceremony from behind grilled (mashrabiya) windows. See E. Fetvac1, Picturing History at the Ottoman Court, Bloomington, IN 2013, pp. 175180; and for the general seclusion of the Ottoman court, including the sultan himself, G. Necipoğlu, Framing the Gaze in Ottoman, Safavid, and Mughal Palaces, "Ars Orientalis” 1993, no. 23, pp. 303-342 
Poullet indeed called the outings of royal women in Iran one of the differences with the near-absolute seclusion of the female members of the Ottoman royal retinue, who almost never went out. ${ }^{41}$ Even a modicum of playfulness can be discerned in later times. Pedros Bedik, an Armenian who resided in Iran in the first half of the $1670 \mathrm{~s}$, insist that, "all men gone, the women magnificently attired, each according to social status, out of curiosity and love for the kind, go outside to see the cavalcade". Chardin and Abbé Carré, writing in the same period, add an important element to this by noting that these women were supposed to appear their best, since if the king's eye fell on one of them or if any pleased his eunuchs while making the rounds, they might be inducted into the royal harem. Armenian women thus would show up in their finery so as to please the shah and be chosen, and they would even come running after the ruler's horse in order to touch him, for entering the harem was a great privilege with many advantages in terms of income and influence. Indeed, to return to one's home and find that one's female relative had been sequestered by the shah was, far from a source of dismay, a cause for joy, for it promised monetary gain and, even more attractively, a possible marriage alliance with the ruler. ${ }^{42}$

In sum, the incidence of quruq in the late Safavid period appears reflective of an increasingly circumscribed public role for women. Father Jacques Villotte SJ, who lived in Isfahan at the turn of the $18^{\text {th }}$ century, even insists that, at that time, quruq applied to white eunuchs and that only the black ones were allowed to accompany the shah and his female retinue. ${ }^{43}$ Yet we may also see this development as an opening, a breathing space in what was clearly becoming an urban environment that simply demanded female protection from the male gaze by way of seclusion. Chardin allows us to entertain this interpretation. The frequent incidence of quruq under Shah Sulayman (r. 1666-1694), he explained, showed the power the shah's women had over this ruler, for it was they who encouraged him to take them on the frequent rides he took upon acceding to power. ${ }^{44}$ The best example, also recounted by Chardin, is that of Nikahat Khanum, Shah Sulayman's mother, who one day, early in the shah's reign, expressed her desire to visit the treasures - gifts offered by foreign envoys, items purchased by the court or acquired as war booty - kept in Isfahan's fortress, Tabarak. The shah granted her wish and organized a special outing under quruq for her. ${ }^{45}$

(304-306). The $18^{\text {th }}$ century may have seen a slightly greater freedom for Ottoman high-class women, enabling them to move about in public with fewer restrictions, although this development may be largely imagined, a function of changing artistic conventions rather than of changes in real life. See T. Artan, Forms and Forums of Expression. Istanbul and Beyond, 1600-1800, [in:] The Ottoman World, ed. Ch. Woodhead, London-New York 2011, pp. 378-406 (397-402).

${ }^{41}$ Sr. Poullet, op. cit., vol. 2, pp. 291-292.

${ }^{42}$ J. Chardin, op. cit., vol. 6, pp. 38-39; B. Carré, op. cit., pp. 261-262.

${ }^{43}$ [P. Villotte], Voyages d'un missionaire de la Compagnie de Jesus en Turquie, en Perse, en Armenie, en Arabie, \& en Barbarie, Paris 1730, p. 149.

${ }^{44}$ J. Chardin, op. cit., vol. 9, p. 553.

45 J. Chardin, op. cit., vol. 10, p. 54. 


\section{Quruq's Growing Incidence}

Quruq was particularly popular under the last three Safavid rulers until the fall of Isfahan to Afghan rebels in 1722: Shah 'Abbas II (r. 1642-1666), Shah Sulayman (r. 1666-1694), and Shah Sultan Husayn (r. 1694-1722). This was a natural function of the fact that all three spent their early years in the royal harem where they had little or no exposure to the outside world. Once enthroned, they took advantage of their new-found freedom to go out riding, often with their wives and concubines. Especially in the last few years of his reign and life, Shah 'Abbas II, having exchanged the rigors of the saddle for the comforts of domesticity, made extensive use of the quruq. Thévenot claims that during the period that he stayed in Isfahan, from October 1664 to March 1665, the shah organized some forty outings under quruq. The same author also tells us that, of late, quruq had become much more burdensome on the locals since previously it had only applied to the direct area traversed by the royal suite but that now the entire surrounding quarter of the town and even villages in the vicinity were blocked off, forcing people to seek shelter anywhere, summer of winter, with those who didn't have relatives or friends in town being forced to head for the mountains. ${ }^{46}$

Shah Sulayman, who, like his father, had been confined to the harem before being enthroned, continued this tradition. He reportedly engaged in sixty-two excursions involving quruq in the first five months of his reign, averaging one every two and a half days. Most of these took place in New Julfa (Isfahan's Armenian quarter), ${ }^{47}$ but some took the royal women to the various parks and villages outside the city ${ }^{48}$ One was organized to the citadel of Isfahan, Tabarak, an object of curiosity for the women since it was the repository of all the objects gathered over time by the court through gifts, purchase, or war booty. ${ }^{49}$ Initially, the formerly cloistered shah went out almost every day. The city of Isfahan was mostly spared in this period, but the suburbs and especially New Julfa were the scene of quruq every ten or twelve days in the first two years of Sulayman's reign, after which the practice slowed down..$^{50}$ According to Chardin, under Sulayman it was no longer allowed for women to show up during the quruq so as to prevent them from running after the royal suite. Chardin intimates that this was done at the behest of the harem women out of jealousy. ${ }^{51}$

Shah Sultan Husayn was very fond of quruq as well. Like the three previous rulers, he grew up in the confines of the palace. Even after coming to power, he spent most of his time in Isfahan, and so much of his entertainment took the form

46 J. de Thévenot, op. cit., p. 337.

${ }^{47}$ For the two successive coronations of Shah Sulayman and the ruler's early reign, see R. Matthee, The Safavid King Who Was Crowned Twice: The Enthronement of Safi Mirza as Shah Safi II in 1077/1666, and as Shah Soleyman in 1078/1668, [in:] Mapping Safavid Iran, ed. N. Kondo, Tokyo 2015, pp. 67-96.

48 J. Chardin, op. cit., vol. 9, p. 552.

49 Ibidem, p. 553.

50 J. Chardin, op. cit., vol. 6, pp. 36-37.

51 Ibidem, pp. 38-39. 
of outings to the various palaces in the vicinity of the capital. According to Father Krusiński he had great fun during these excursions, whipping the assess on which his women's maid servants rode "till they threw their riders, and made sport for the others". ${ }^{52}$ Under Sultan Husayn, the number of women and eunuchs grew into the thousands, causing outings to involve an ever growing throng of royal women, their maid servants and their guardians ${ }^{53}$ Figures about the size of the royal harem are invariably supplied by foreigners, and it is difficult to distinguish between hearsay and reliable informants as the source of their knowledge. Yet successive sources do suggest steady growth. According to the English merchant Jenkinson, writing in the $1560 \mathrm{~s}$, Shah Tahmasb, had 140 women in his harem. ${ }^{54}$ The Carmelite missionaries estimated the number of women in Shah 'Abbas I's harem to be "several hundred". ${ }^{55}$ Arak"el of Tabriz claimed that under Shah 'Abbas II the number of court eunuchs had increased since the shah "had taken many wives from various nations and had thus gathered many eunuchs". ${ }^{56}$ Raphaël du Mans gave a figure of 300 to 400 for the harem of Shah 'Abbas II. ${ }^{57}$ Bedik mentions 500 for the harem of Shah Sulayman. These were served by some 3,000 eunuchs, if we are to believe Chardin. ${ }^{58}$ By the time Shah Sultan Husayn came to power in 1694, the shah's female entourage had reportedly grown to over 800 , and the total court is said to have employed some 14,000 people..$^{59}$

The movement of a suite of this magnitude naturally became a major undertaking. One source records how in December 1694, a little over four months after his enthronement in August, Sultan Husayn went on his first hunting outing in the vicinity of Isfahan, and how the royal suite consisted of a staggering and unprecedented number of more than 6,000 horses. ${ }^{60}$ Almost two years later, in November 1696, Sultan Husayn took more than 500 women on another hunting trip under quruq, leaving many others behind in the royal harem. ${ }^{61}$ In December 1717 the royal entourage, consisting of c. 1,000 women supervised by c. 200 eunuchs, entered Kashan on 525 camels. $^{62}$

52 J.T. Krusiński, The History of the Revolutions of Persia, 2 vols, London 1733, vol. 1, p. 123.

${ }^{53}$ Ibidem, pp. 123-124.

${ }^{54}$ A. Jenkinson, Early Voyages and Travels to Russia and Persia, ed. E. Delmar Morgan, C.H. Coote, 2 vols, New York 1886, vol. 2, p. 134.

${ }^{55}$ [Herbert Chick] (ed.), A Chronicle of the Carmelites and the Papal Mission to Persia, 2 vols paginated as one, London 1939; repr. 2012, p. 168.

${ }^{56}$ Arak'el of Tabriz, The History of Vardapet Arak'el of Tabriz, trans. and ed. G. Bournoutian, 2 vols paginated as one, Costa Mesa, Cal. 2005, vol. 2, p. 339.

${ }^{57}$ R. du Mans, Estat de 1660, [in:] Raphaël du Mans..., vol. 2, p. 19.

${ }_{58}$ P. Bedik, op. cit., p. 250; J. Chardin, op. cit., vol. 6, pp. 24, 40-42.

${ }^{59} \mathrm{~N}$. Sanson, op. cit., p. 88. Compare this to the Ottoman harem, which is said to have grown from c. 150 in the mid-16 $6^{\text {th }}$ century to a little over 500 in the 1650 s. See L.P. Peirce, The Imperial Harem: Women and Sovereignty in the Ottoman Empire, New York-Oxford 1993, p. 122. As several authors, among them du Mans and Sanson, noted, the numbers given for the royal harem included all the females in the shah's entourage, including the servants.

${ }^{60}$ P. Gaudereau, Relation de la mort de Schah Abbas, roi de Perse, et du couronnement de Sultan Ussain, son fils, [in:] Nouvelles d'Ispahan 1665-1695, ed. A. Kroell, Paris 1979, p. 69.

${ }^{61}$ G. Pereira Fidalgo, L'Ambassade de Gregório Pereira Fidalgo à la cour de Châh Soltân Hosseyn 1696-1697, ed. J. Aubin, Lisbon 1971, pp. 52-53.

62 P.P. Bushev, Posol'stvo Artemiia'..., p. 204. 
We have several other references to Sultan Husayn's outings under quruq. One is from the pen of English and Dutch East India company agents and narrates the shah's visit to the factory of the English East India Company in Isfahan on 24 July 1699. This visit began with a stroll through town which the ruler took on 22 July, unaccompanied by his female retinue, during which he passed the house of the English. Curious, he inquired about the nature and function of the EIC and next decided to pay their residence a visit with his female entourage. The event took place two days later, forcing the EIC agents to scramble to finish preparations for a lavish "sugar banquet". ${ }^{63}$ Less than a week later, on 30 July 1699, the shah visited Isfahan's castle, Tabarak, with his women. ${ }^{64}$

No doubt the costliest and most elaborate quruq of all time was the pilgrimage Shah Sultan Husayn undertook to the shrine of the Eighth Imam of Twelver Shi ism, Imam Riza, in Mashhad in the summer of 1706. The shah set out with all his women and a retinue of some 60,000 people, causing the Dutch to complain of a capital deprived of so much of its (moneyed) population that its trade came to a virtual halt. ${ }^{65}$ The royal suite traveled the nearly 800 miles from Isfahan to Mashhad under quruq, with quruqchis preceding and following the cavalcade at a mile's distance. The journey, including the shah's residence in Mashhad, took well over a year and proved to be ruinous for the treasury as much as for the countryside through which it traveled. ${ }^{6}$ During the four months that the shah and his suite resided in Mashhad, quruq was maintained. The embargo became so onerous on the local population and especially on the merchants of the bazaars that it was decided to build a covered corridor, dalan-i musaqqaf, alongside all the houses lining the stretch from the Chahar Bagh to the entrance of the shrine so the royal cortège could visit the sanctuary without hindering the business of the city. ${ }^{67}$

\section{Personal Encounters}

Almost all European travelers who spent more than a few weeks in Isfahan in the late Safavid period report experiencing quruq firsthand. De Silva y Figueroa, traveling between Qazvin and Isfahan, was told not to come too close to the litters - wooden boxes measuring three feet in length, two feet in width, and one foot in height, topped by boards forming a cover - conveying (invisible) Kurdish, Georgian and Persian women while he rode past the camels that carried them. He noted that if the women were of any importance, they would be accompanied by eunuchs who rode ahead of them while shouting to everyone within earshot that they should turn their backs or retreat out of sight. Anyone who disobeyed this command risked being forced to the ground face-

63 See R. Matthee, A Sugar Banquet for the Shah: Anglo-Dutch Competition at the Iranian Court of Šāh Sultān Husayn, "Eurasian Studies” 2006, pp. 195-218 (205 ff.)

64 Ibidem, pp. $213 \mathrm{ff}$.

65 Nationaal Archief (Dutch National Archives), The Hague, VOC 1747, Backer, Isfahan to Casteleyn, Gamron, 6 Oct. 1706, fol. 279.

66 J.T. Krusiński, op. cit., vol. 1, p. 127.

67 Muhammad Muhsin Mustawfi, Zubdat al-tavarikh, ed. B. Gudarzi, Tehran 1375/1996, p. 116. 
down and beaten with a stick. ${ }^{68}$ Thévenot, on his way from Isfahan to Bandar 'Abbas in February 1665, saw his route blocked near the town of Qumshah near Yazdikhast, in Fars. His traveling party encountered the khan of Shiraz with his retinue, suggesting, like De Silva y Figueroa, that provincial magistrates organized their own outings under quruq. He was forced to interrupt his journey and make a substantial detour. ${ }^{69}$ Chardin's claims that during his stay in Isfahan quruq forced him to evacuate and to sleep outside twice and to leave his home once at midnight. ${ }^{70}$ In April 1669 the Abbé Carré got caught up in one of Shah Sulayman's quruqs, preventing him from returning from Isfahan to New Julfa. ${ }^{71}$ In the summer of 1695, a Carmelite delegation led by Bishop Pidou of Baghdad while traveling from Hamadan to Isfahan was held up for three days approaching the capital, forced to dwell in a tent, because Shah Sultan Husayn and his wives were visiting gardens in the vicinity under quruq. ${ }^{72}$ And the Dutch painter-traveler Cornelis de Bruyn, whose observations date from 1703, offers an eye-witness account that confirms the practice of literally shielding the royal outings from view, claiming that during quruq, all streets intersecting with the Chahar Bagh in Isfahan were surveilled by guardians and hidden from view by way of cloth enclosures. ${ }^{73}$ De Bruyn tells his readers how at various times he and his travel companions had to move out of caravanserais to make room for high officials traveling under quruq. He gives some detail about the time when he was caught unawares and became involved in an unannounced quruq in Isfahan. Everyone ran for his life when the quruqchis summoned everyone off the road, and he, too, made sure to seek safety turning into side streets. De Bruyn describes how at every street corner there was a quruqchi who pointed out which way to go and which turns to take. ${ }^{74}$

All those who describe the practice of quruq emphasize the draconian nature of the punishment for violators and the swiftness and irrevocability with which it was executed, either with knives or with pistols shots. Yet the anecdotes they offer also show the other, equally arbitrary, side of "Oriental" justice, in the form of the royal capacity to be forgiving, even magnanimous. The Armenian

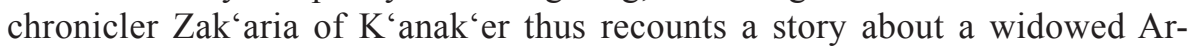
menian priest who, oblivious to his surroundings, happened upon a party of Shah 'Abbas I and his women. Horror-struck and fearing for his life for having trespassed into a forbidden zone, he hid by throwing a cassock over his head. Interrogated, he confessed guilt, asking for clemency as an innocent priest. The shah, instead of having him killed, in response offered him any one of the women present. He aeclined the gift, with the argument that the females offered to

${ }^{68}$ G. de Silva y Figueroa, op. cit., p. 491, adding that, if the shah's women were involved, disobeying the order would result in death regardless of the offender's rank or preeminence.

69 J. de Thévenot, op. cit., pp. 418-419.

70 J. Chardin, op. cit., vol. 6, p. 36.

71 B. Carré, op. cit., p. 261.

72 [H. Chick] (ed.), op. cit., vol. 1, p. 472.

73 C. de Bruyn, Reizen over Moskovie door Persie en Indie, Amsterdam 1714, p. 189.

74 Ibidem, pp. 189-190. 
him were all his "mothers, sisters and daughters". The monarch next tested the prelate's resolve by forcing him to down a large ladle filled with wine - a so called hazar-pisha - in one gulp. When the priest, having performed the feat, persisted in his refusal, the shah released him with a sealed note signed by himself, a safeguard against the royal eunuchs. ${ }^{75}$

Tavernier's travelogue relates a similar incident that occurred under Shah 'Abbas II which did not end so well. A valet who had helped set up the tents for the court in the countryside had fallen asleep, exhausted from the labor, to be found by the shah's women when they entered the tent. The eunuchs thereupon rolled him up in the carpet on which he had been resting and buried him alive. ${ }^{76}$ In another anecdote told by Tavernier an old man decided to present a request to Shah Sulayman, thinking that his old age would make him look like a eunuch. He was wrong, for he was struck down by the shah who pierced him with two arrows. ${ }^{77}$

Far luckier was the villager in the account of the Italian traveler Giovanni Gemelli-Careri, who visited Iran in the last year of Shah Sulayman's reign but whose story must refer to the time before the shah disappeared into his harem in c. 1690. Returning from his land with a donkey laden with peaches, he happened upon the suite of Shah Sulayman. He, too, prostrated himself before the monarch, trembling, eyes closed. The shah was so pleased with the demeanor of the simple rustic that he summoned him to get up. The peasant only did so after being told three times. The shah thereupon ordered the women around him to buy the peasant's peaches and each to give him a ducat (zecchino). Not only that, he was invited to choose whichever woman in the shah's entourage pleased him the most, so that he returned home with his pockets filled and with the most beautiful woman of all of Persia. ${ }^{78}$

Gregório Pereira Fidalgo, who in 1696 came to Isfahan as Portugal's emissary, offers an anecdote that he said he had heard from his officially appointed host-minder, mehmandar, and which reflects Shah Sultan Husayn's legendary kindheartedness. At one point the monarch had gone out to hunt accompanied by his female retinue. Naturally, the quruqchis had first notified the inhabitants of the surrounding area, summoning them to make themselves scarce. Yet one peasant failed to learn of the embargo and was still tilling his soil when the royal suite passed. The shah was the first to spot the poor soul. The latter, realizing that his life hung in the balance, threw himself on the ground before the monarch, covering his face. Shah Sultan Husayn was so pleased with this gesture that, so as to keep the eunuchs from executing the man, he took off his gold-brocaded mantle and threw it over the fellow. This, however, did not prevent the approaching eunuchs from taking a few shots at him, killing him. The shah is said to have shown his regrets, although it remained unclear if he punished the perpetrators. ${ }^{79}$

${ }^{75} Z^{2}$ ak'aria of K'anak'er, The Chronicle of Deacon Zak'aria of K'anak'er, trans. and ed. G. Bournoutian, Costa Mesa, Cal. 2004, pp. 52-53.

${ }^{76}$ J. Chardin, op. cit., vol. 6, p. 35; J.-B. Tavernier, op. cit., vol. 1, p. 636.

77 J. Chardin, op. cit., vol. 6, p. 36.

${ }^{78}$ G. Gemelli-Careri, op. cit., vol. 2, p. 172.

79 G. Pereira Fidalgo, op. cit., pp. 54-55. 
By the early $18^{\text {th }}$ century, this type of encounter, with varying outcomes, had clearly become something of a trope. How much especially the story of the peasant who not only escaped with his life thanks to royal benevolence but returned home with a gorgeous wife resonated is shown by Father Villotte who offered a plotline identical to the one offered by Gemelli-Careri. Only this time the monarch in question was Shah 'Abbas I, who long since had become a legend himself. ${ }^{80}$

\section{Quruq after the Safavids}

Quruq continued following the fall of Isfahan to the Afghans in October 1722, although information on the practice is sparse. The Dutch report how Nadir Shah declared quruq whenever he left his camp, "so that all door and windows ha[d] to be closed, and those who [we]re about or [we]re seen, lost their lives". ${ }^{81}$ In 1737, Nadir Shah ordered his treasurer, Mirza Abu'l Hasan, to take Tahmasb III's women, who were still in Isfahan with their servants and eunuchs, under quruq to Sabzavar, where the ex-shah was residing at that point. ${ }^{82}$ And in 1741 an undetected male intruder into the orbit delineated by quruq took a shot at Nadir Shah and came within an inch of killing him. ${ }^{83}$

The practice of quruq persisted far into the $19^{\text {th }}$ century. Jacob Polak, the Austrian physician who taught medicine in Iran between 1851 and 1860 and who served as Nasir al-Din Shah's first private physician, observed that the royal women were ordinarily not allowed to enter the outer reaches of the royal palace but that, occasionally, the shah would release all male attendants and allow the women onto the premises under quruq. Polak also refers to the surviving custom of declaring quruq whenever a royal lady went out riding. ${ }^{84}$ Indeed, in the early reign of Nasir al-Din Shah (r. 1848-1896) royal women continued to go out, if they went out at all, under quruq, their carriages preceded by officials who would clear the way, shouting kur shu, dur shu (close your eyes; get lost; lit. become blind, remove yourself). Every month the court would organize an outing for the shah and his women to visit the gardens and the Gulistan Palace with musical entertainment. ${ }^{85}$

But change was coming. In the summer of 1869 , some twenty years into Nasir al-Din Shah's reign, a royal edict was issued that amended the rules for the members of foreign legations in Iran. Henceforth males were no longer obliged to

${ }^{80}$ [P. Villotte], op. cit., pp. 150-151.

${ }^{81}$ In W. Floor, trans. and ed., The Rise and Fall of Nader Shah: Dutch East India Company Reports, 1730-1747, Washington, D.C. 2009, p. 91.

82 In ibidem, pp. 70-71.

83 J. Hanway, An Historical Account of the British Trade over the Caspian Sea..., 4 vols, London 1753, vol. 1, p. 24.

${ }^{84}$ J.E. Polak, Persien: Das Land und seine Bewohner - Ethnographische Schilderungen, 2 vols, Leipzig 1865, vol. 1, p. 235.

85 Abu'l Qasim Tafazzuli, Az Furugh al-Saltana ta Anis al-Dawla. Zanan-i haramsara-y Nasir al-Din Shah, Tehran 1377/1999, pp. 47, 161. 
leave town for the duration of a royal outing with female company. They now had to turn their backs until the royal cortège had passed. Yet foreign legations were still supposed to keep their doors shut. This caused their representatives to lodge a protest, as a result of which it was announced that, while members of the foreign community were held to maintain an appropriate attitude for the duration of the quruq, they no longer had to keep their doors closed. ${ }^{86}$

These were the waning days of quruq. Charles James Willes, a British physician who lived in Iran between 1866 and 1881, observed how in the 1870s the custom was dying out. He noted how a certain death used to await any man who found himself in the neighborhood of the royal wives during one of their numerous outings. The people, he added, "always fled, or stood with faces to the wall; and Europeans when they saw the eunuchs' procession approaching, and heard the cry of 'Gitchen,' (Turkish, 'Be gone'), to avoid unpleasantness and possible rows, used to turn down the first street". Wills follows the model of the $17^{\text {th }}$-century European observers by telling an amusing anecdote about Albert Gasteiger, an Austrian engineer who lived in the country for the better part of the period 1860-1888, engaged by the shah to train the Iranian army and help build the country's first modern roads. Gasteiger Khan, as he was called in Iran, would turn his face to the wall, like a native, and "as each carriage passed, deliberately saluted from the back of his head". This delighted the royal ladies, who informed the shah about the oddity. The latter summoned the Austrian engineer and had him do the salute in front of him, and "after laughing a good deal, gave him a handsome present". ${ }^{87}$

Lord Curzon, writing in c. 1890 , observed how at that time the system of quruq was disappearing. Alluding to the changes that had taken place in 1869, and which two decades later apparently applied to all males, he noted that, "in the present reign males are expected to turn to the wall when the royal cortège passes, but the old horrors of the kuruk have disappeared". Curzon noted how a "labourer, who, pursuing an underground kanat found himself in the andarun of the royal palace, was spared by the Shah, although his life would certainly have been forfeited in any previous reign". He attributed this as well as the general obsolescence of the practice of quruq, part of what he called the "fortunate amelioration of manners" in late $19^{\text {th }}$-century Iran, "both to the character of the sovereign and to the immense, though perhaps grudgingly acknowledged, influence of foreign opinion, and of the representatives of foreign Powers at the Persian Court". ${ }^{88}$ Much had indeed changed by then. As Curzon was composing his two-volume history of Iran, quruq continued to be upheld at Nasir al-Din Shah's court, to be lifted in the

${ }^{86}$ Archives des Affaires Etrangères, Paris, Corr. Politique, Perse, 35, De Bonmèrès, Tajrish to Paris, 22 Sept. 1869 , fols. $78 \mathrm{v}-80$.

${ }^{87}$ C.J. Wills, The Land of the Lion and the Sun (Modern Persia), new ed., London-New YorkMelbourne 1891, p. 371. Gasteiger seems to have been a charming person of good humor who was well liked by the shah. He apparently had an excellent relationship with Nasir al-Din Shah, to the point where the Austrian even managed to become familiar with some of the shah's family members. See H. Praxmarer, Albert Gasteiger Khan (1823-1890). Reisebriefe aus Persien nach Tirol, Innsbruck 2013, pp. 41-42.

${ }^{88}$ G.N. Curzon, Persia and the Persian Question, 2 vols, London 1892, vol. 1, p. 404. 
morning. ${ }^{89}$ The shah also would still declare quruq a few nights every month, so as to allow the women of his court to stroll around and amuse themselves in the palace gardens, free from the male gaze. ${ }^{90}$ Yet in 1890 he permitted his favorite concubine, Zubayda Amina Aqdas, to travel to Vienna, not under the protection of quruq, as was recommended by his courtiers - who suggested that she remain on Islamic soil by traveling as far as Istanbul, located within reach of European specialists - but only accompanied by a eunuch and some service personnel, to undergo an eye operation at the hands of the renowned Professor Ernst Fuchs. ${ }^{91}$

It is rather ironic, finally, to learn how Nasir al-Din Shah's assassination on May $1^{\text {st }} 1896$ might have been prevented if quruq had been in place at the shrine of Shah 'Abd al-'Azim on that day. The shah's chamberlain recommended declaring quruq on account of the large number of people thronging the shrine during the royal visit. The shah rejected this, though, arguing that he did not want to burden people with this restrictive measure, all the more so since he intended to go to Shah 'Abd al-Azim to perform a pilgrimage in order to give thanks for his fifty years on the throne, the celebration of which was imminent. This allowed Mirza Riza Kirmani to draw close to the monarch after the latter got up from his prayer and shoot him at close range. ${ }^{92}$

\section{Conclusion}

Originating as a Mongol term denoting a burial site or a hunting ground taboo and off-limits to anyone but the ruler, quruq in the course of the Safavid period came to stand for an embargoed zone protecting females of high rank and in particular women of the royal court. This shift in meaning and the rather sudden appearance of quruq as an enclosed space for court women at the turn of the $17^{\text {th }}$ century clearly reflects the transition of the Safavids from a steppe dispensation to a sedentary order and the attendant loss of mobility of the shah and his entourage. Quruq thus was a function of urban living and the seclusion it mandated, substituting, in a paradoxical way, controlled mobility for the free-range mobility of the erstwhile ambulant court. Shah 'Abbas's choice of Isfahan as Iran's first real capital is a signal moment in this development, and it is no accident that our first real description of quruq involves an all-female spectacle on the royal square and the adjacent bazaar during that shah's reign. As Shah 'Abbas's successors more and more retreated into the palace, the incidence of quruq only grew, allowing the women of the court to enjoy at least a modicum of "freedom", certainly compared

89 I'timad al-Saltana, Ruznamah-i khatirat-yi I'timad al-Saltana, ed. I. Afshar, 4 ${ }^{\text {th }}$ ed., Tehran 1377/1998, p. 339.

90 Dust 'Ali Khan Mu'ayyir al-Mamalik, Yaddashtha-i az zindigani-yi khususi-yi Nasir al-Din Shah, $3^{\text {rd }}$ ed., Tehran 1373/1994, p. 22.

${ }^{91}$ H. Slaby, Bindenschild und Sonnenlöwe: Die Geschichte der österreichisch-iranischen Beziehungen bis zur Gegenwart, Graz 1982, p. 208; and Amin al-Dawla, Khatirat-i Amin al-Dawla, ed. H. Farmanfarmiyan, Tehran 1362, p. 135.

92 Amin al-Dawla, op. cit., pp. 207-208; Dust 'Ali Khan Mu'ayyir al-Mamalik, op. cit., p. 104; and Y. Dawlat Abadi, Hayat-i Yahya, 4 vols, $4^{\text {th }}$ ed., Tehran 1362/1983, vol. 1, pp. 144-145. 
to their Ottoman sisters, who, immured in the Topkap1 Palace, in this period never seem to have gone out riding, or for that matter, the royal women of $16^{\text {th }}$ and $17^{\text {th }}$-century Russia, who lived cloistered lives in the terem, an institution similar to the harem..$^{93}$ With that, the nuisance these royal outings created for the common people living in or near the path of the cavalcade was substantial and growing, as is amply documented by the foreign observers who, encountering them, were forced, like all males, to vacate their homes or make detours and incur delays. In the course of the $17^{\text {th }}$ century quruq became common but it always remained a custom; it never became institutionalized by being included in the bureaucratic apparatus and nomenclature. The term and the practice thus do not appear in any of the three surviving Safavid manuals of state, the Tazkirat al-Muluk, the Dastur al-Muluk, and the Alqab va Mavajib. ${ }^{94}$

\section{Bibliography}

d'Alessandri V., Narrative of the Most Noble Vincentio d'Alessandri, [in:] A Narrative of Italian Travels in Persia in the Fifteenth and Sixteenth Centuries, ed. Ch. Grey, London 1873.

Allsen T.T., The Royal Hunt in Eurasian History, Philadelphia 2006, pp. 116-117.

al-Mamalik, Dust 'Ali Khan Mu'ayyir, Yaddashtha-i az zindigani-yi khususi-yi Nasir al-Din Shah, 3rd ed., Tehran 1373/1994.

Amin al-Dawla, Khatirat-i Amin al-Dawla, ed. H. Farmanfarmiyan, Tehran 1362.

Ansâri, Mohammad Rafi' al-Din, Dastur al-Moluk. A Safavid State Manual, trans. and ed. W. Floor, M.H. Faghfoory, Costa Mesa, Cal. 2007.

Arak'el of Tabriz, The History of Vardapet Arak'el of Tabriz, trans. and ed. G. Bournoutian, 2 vols paginated as one, Costa Mesa, Cal. 2005.

Archives des Affaires Etrangères, Paris, Corr. Politique, Perse, 35, De Bonmèrès, Tajrish to Paris, 22 Sept. 1869, fols. $78 \mathrm{v}-80$.

Artan T., Forms and Forums of Expression. Istanbul and Beyond, 1600-1800, [in:] The Ottoman World, ed. Ch. Woodhead, London-New York 2011, pp. 397-402.

${ }^{93}$ Conditions in the Mughal Empire at the time apparently resembled those in Iran, albeit without the same strict gender segregation. The Venetian Niccolao Manucci, who spent most of his adult life in India, a period coinciding with the reign of Sultan Aurangzeb (1658-1707), had this to say about the outings of the Mughal "princesses of the blood": ... perceiving the approach of these princesses, everybody forthwith hastens out of the way. They proceed very slowly, men in front, sprinkling water on the roadway to lay the dust. They are placed in a palanquin which has over it a rich cloth or net of gold sometimes ornamented with precious stones or pieces of looking glass. The eunuchs surround the palanquin, driving away the flies with peacock-feathers stuck into handles of enameled gold-work or adorned with precious stones. The men-servants hold sticks of gold and silver in their hands and call out, "Out of the way! Out of the way!" See N. Manucci, Storia di Mogor. Or Mogul India 1653-1708, trans. and ed. W. Irvine, 4 vols, London 1907-1908, vol. 1, p. 220.

94 Tadhkirat al-Mulūk. A Manual of Șafavid Administration, trans. and ed. V. Minorsky, Cambridge 1943; repr. 1980; Mohammad Rafi ' al-Din Ansâri, Dastur al-Moluk. A Safavid State Manual, trans. and ed. W. Floor, M.H. Faghfoory, Costa Mesa, Cal. 2007; Mirza 'Ali Naqi Nasiri, Alqab va mavajib-i dowra-i salatin-i Safaviya, ed. Y. Rahimlu, Mashhad 1371/1992; trans. as Titles and Emoluments in Safavid Iran. A Third Manual of Safavid Administration, trans. and ed. W. Floor, Washington 2008. 
Babur, Zahiru' d-dīn Muhammad Pādshāh Ghāzī, The Bābur-nāma in English, trans. A.S. Beveridge, London 1921.

Barthold V.V., Rogers J.M., The Burial Rites of the Turks and the Mongols, "Central Asiatic Journal" 1970, no. 14, pp. 195-227.

Bedik P., A Man of Two Worlds. Pedros Bedik in Iran 1670-1675, trans. and annotated C. Ouahes, W. Floor, Washington, D.C. 2014.

Bell W. et al., Oct. 15 1624, and 9 Jan. 1625, Ispahan, [in:] Calendar of State Papers Colonial, East Indies, China and Japan, Volume 4, 1622-1624, ed. W.N. Sainsbury, London 1878.

Brosset M. (ed.), Collection d'historiens arméniens, 2 vols, St. Petersburg 1874.

de Bruyn C., Reizen over Moskovie door Persie en Indie, Amsterdam 1714.

Bushev P.P., Istoriia posols'stv $i$ diplomaticheskikh otnoshenii russkogo i iranskogo gosudarstv v 1613-1621 gg., Moscow 1987.

Bushev P.P., Posol'stvo Artemiia Volynskogo v Iran v 1715-1718 gg., Moscow 1987.

Carré B., Le Courier du Roi en Orient. Relations de deux voyages en Perse et en Inde 1668-1674, Paris 2005.

Chardin J., Les voyages du Chevalier Chardin, en Perse et aux Indes et autres lieux de l'Orient, 10 vols and atlas, ed. L. Langlès, Paris 1810-1811.

[Chick H.] (ed.), A Chronicle of the Carmelites and the Papal Mission to Persia, 2 vols paginated as one, London 1939; repr. 2012.

Curzon G.N., Persia and the Persian Question, 2 vols, London 1892.

Dawlat Abadi Y., Hayat-i Yahya, 4 vols, 4th ed., Tehran 1362/1983.

Della Valle P., Delle conditioni di Abbàs Rè di Persia, Venice 1628; repr. Tehran 1976.

Della Valle P., Viaggi di Pietro della Valle il pellegrino, 2 vols, ed. G. Gancia, Brighton 1843.

Doerfer G., Türkische und mongolische Elemente im Neupersischen. Unter besonderer Berücksichtigung älterer neupersischen Geschichtsquellen vor allem der Mongolenund Timuridenzeit, 3 vols, Wiesbaden 1967.

Fetvac1 E., Picturing History at the Ottoman Court, Bloomington, IN 2013.

Findiriski, Sayyid Abu Talib Musavi, Tuhfat al-'alam (dar awsaf va akhbar-i Shah Sultan Husayn Safavi), ed. R. Ja fariyan, Tehran 1388/2009.

Floor W. (trans. and ed.), The Rise and Fall of Nader Shah: Dutch East India Company Reports, 1730-1747, Washington, D.C. 2009.

Gaudereau P., Relation de la mort de Schah Abbas, roi de Perse, et du couronnement de Sultan Ussain, son fils, [in:], Nouvelles d'Ispahan 1665-1695, ed. A. Kroell, Paris 1979.

Gemelli-Careri G., Giro del mondo, 6 vols, Naples 1699.

Hafiz-i Abru, Zubdat al-tavarikh, 2 vols in 4 tomes, ed. Hajj Sayyid Javadi, vol. 1(1-2), Tehran 1380/2001.

Hanway J., An Historical Account of the British Frade over the Caspian Sea, 4 vols., London 1753.

Herbert T., Travels in Persia, 1627-1629, London 1928.

Isfahani, Muhammad Ma'sum b. Khajigi, Khulasat al-siyar. Tarikh-i ruzgar-i Shah Safi Safavi, ed. I. Afshar, Tehran 1368/1989.

I'timad al-Saltana, Ruznamah-i khatirat-i I'timad al-Saltana, ed. I. Afshar, 4th ed., Tehran 1377/1998.

Jenkinson A., Early Voyages and Travels to Russia and Persia, ed. E. Delmar Morgan, C.H. Coote, 2 vols, New York 1886. 
K'anak'er, Zak'aria of, The Chronicle of Deacon Zak'aria of K'anak'er, trans. and ed. G. Bournoutian, Costa Mesa, Cal. 2004.

Kaempfer E., Exotic Attractions in Persia, 1684-1688. Travels and Observations, trans. and annotated W. Floor, C. Ouahes, Washington, D.C. 2018.

Khuzani Isfahan, Fazli Beg, A Chronicle of the Reign of Shah 'Abbas, ed. K. Ghereghlou, 2 vols paginated as one, Exeter 2015.

Khvandamir, Tarikh-i habib al-siyar, 4 vols, ed. J. Huma'i, M. Dabir-Siyaqi, Tehran $1362 / 1983$.

Krusiński J.T., The History of the Revolutions of Persia, 2 vols, London 1733.

du Mans R., Estat de 1660, and Estat de 1684, [in:] Raphaël du Mans missionnaire en Perse au XVIIe siècle, ed. F. Richard, 2 vols, Paris 1995, vol. 2, pp. 4-199, 279-381.

Manucci N., Storia di Mogor. Or Mogul India 1653-1708, trans. and ed. W. Irvine, 4 vols, London 1907-1908.

Matthee R., A Sugar Banquet for the Shah: Anglo-Dutch Competition at the Iranian Court of Šāh Sultān Husayn, "Eurasian Studies” 2006, pp. 195-218.

Matthee R., The Safavid King Who Was Crowned Twice: The Enthronement of Safi Mirza as Shah Safi II in 1077/1666, and as Shah Soleyman in 1078/1668, [in:] Mapping Safavid Iran, ed. N. Kondo, Tokyo 2015, pp. 67-98.

Membré M., Mission to the Lord Sophy of Persia (1539-1542), trans. and ed. A.H. Morton, London 1993.

Munajjim, Mulla Jalal al-Din, Tarikh-i 'Abbasi ya ruznama-yi Mulla Jalal, ed. Sayf Allah Vahid Niya, Tehran 1366/1987.

Mustawfi Muhammad Muhsin, Zubdat al-tavarikh, ed. B. Gudarzi, Tehran 1375/1996.

Naqi Nasiri, Mirza 'Ali, Alqab va mavajib-i dowra-yi salatin-i Safaviya, ed. Y. Rahimlu, Mashhad 1371/1992; trans. as Titles and Emoluments in Safavid Iran. A Third Manual of Safavid Administration, trans. and ed. W. Floor, Washington, D.C. 2008.

Narshakhi, Abu Bakr Muhammad b. Ja'far, Tarikh-i Bukhara, trans. Abu Nasr Ahmad Muhammad b. Nasr al-Qubadi, Tehran 1351/1972.

Nasiri, Muhammad Ibrahim b. Zayn al-'Abidin, Dastur-i shahriyaran, ed. M.N. Nasiri Muqaddam, Tehran 1373/1994.

Nationaal Archief (Dutch National Archives), The Hague, VOC 1747, Backer, Isfahan to Casteleyn, Gamron, 6 Oct. 1706, fol. 279.

Necipoğlu G., Framing the Gaze in Ottoman, Safavid, and Mughal Palaces, "Ars Orientalis" 1993, no. 23, pp. 304-306.

O'Kane B., From Tents to Pavilions: Royal Mobility and Persian Palace Design, "Ars Orientalis" 1993, no. 23, pp. 249-268.

Olearius A., Vermehrte newe Beschreibung der muscowitischen und persischen Reyse, Schleswig 1656, repr. Tübingen 1971.

Omidsalar M., Čerāḡān̄i, [in:] Encyclopaedia Iranica, vol. 5, London 1991, pp. 264 265.

Online Etymology Dictionary, http:/www.etymonline.com/index.php?term=forest (access: 2.05.2019).

Peirce L.P., The Imperial Harem: Women and Sovereignty in the Ottoman Empire, New York-Oxford 1993.

Pereira Fidalgo G., L'Ambassade de Gregório Pereira Fidalgo à la cour de Châh Soltân Hosseyn 1696-1697, ed. J. Aubin, Lisbon 1971. 
Polak J.E., Persien: Das Land und seine Bewohner - Ethnographische Schilderungen, 2 vols, Leipzig 1865.

Poullet S., Nouvelles relations du Levant, 2 vols, Paris 1668.

Praxmarer H., Albert Gasteiger Khan (1823-1890). Reisebriefe aus Persien nach Tirol, Innsbruck 2013.

Samarqandi, Kamal al-Din 'Abd al-Razzaq, Matla'-i sa dayn va majma 'al-Bahrayn, 4 vols in 2 tomes, ed. 'A. Nava'i, vol. 1, Tehran 1383/2004.

Sanson N., Estat présent du royaume de Perse, Paris 1694.

Schillinger F.C., Persianische und Ost-Indianische Reis: Welche Frantz Caspar Schillinger von Ettlingen der Marggrafschafft Baaden ... durch das Türckische Gebiet im Jahr 1699 angefangen und 1702 vollendet, Darbey ein warhaffter Bericht etlicher Begebenheiten die sich Zeit solcher vierjährigen Reise... zugetragen, Nuremberg 1701.

Schweigger S., Ein newe Reyssbeschreibung auss Teutschland nach Constantinopel und Jerusalem, ed. R. Neck, Graz 1964.

Shami, Nizam al-Din, Zafarnama, Histoire des conquêtes de Tamerlan, ed. F. Tauer, Prague 1937.

de Silva y Figueroa, Don García, Comentarios de la Embaxada al Rey Xa Abbas de Persia (1614-1624), ed. R.M. Loureiro, A.C. Costa Gomes, V. Resende, 2 vols paginated as one, Lisbon 2011.

Slaby H., Bindenschild und Sonnenlöwe: Die Geschichte der österreichisch-iranischen Beziehungen bis zur Gegenwart, Graz 1982.

Smith R.B. (ed.), The First Age of the Portuguese Embassies, Navigations and Peregrinations in Persia (1507-1524), Bethesda, MD 1970.

Szuppe M., Status, Knowledge and Politics: Women in sixteenth-Century Safavid Iran, [in:] Women in Iran from the Rise of Islam to 1800, ed. G. Nashat, L. Beck, UrbanaChicago 2003, pp. 140-169.

Tadhkirat al-Mulūk. A Manual of Șafavid Administration, trans. and ed. V. Minorsky, Cambridge 1943.

Tafazzuli Abu'l Qasim, Az Furugh al-Saltana ta Anis al-Dawla. Zanan-i haramsara-yi Nasir al-Din Shah, Tehran 1377/1999.

Tarikh-i 'Alam-ara-yi 'Abbasi, 2 vols. paginated as one, ed. I. Afshar, 2nd ed., Tehran 1350/1971.

Tavernier J.-B., Les six voyages de Jean Bapt. Tavernier ... en Turquie, en Perse, et aux Indes, 2 vols, Paris 1686.

de Thévenot J., Les voyages de Mr. De Thévenot. Suite de voyage au Levant, vol. 3, Paris 1727.

[Villotte P.], Voyages d'un missionaire de la Compagnie de Jesus en Turquie, en Perse, en Armenie, en Arabie, \& en Barbarie, Paris 1730.

Wills C.J., The Land of the Lion and the Sun (Modern Persia), new ed., London-New York-Melbourne 1891.

Yazdi, Sharaf al-Din 'Ali, Zafar-nama, 2 vols paginated as one, ed. 'A. Nava'i, M. Sadiq, Tehran 1387/2008.

Zeno C., Travels in Persia [in:] A Narrative of Italian Travels in Persia in the Fifteenth and Sixteenth Centuries, ed. Ch. Grey, London 1873. 